\title{
Interwencja państwa za pomocą instrumentów polityki innowacyjnej: wprowadzenie bodźców podatkowych w celu zwiększenia nakładów na działalność badawczo-rozwojową w Polsce
}

\begin{abstract}
Streszczenie
W ujęciu globalnym bodźce podatkowe są obecnie jednym z najpopularniejszych narzędzi interwencji państwa, mających na celu wsparcie rozwoju działalności badawczo-rozwojowej. W ujęciu historycznym wzrost popularności ww. instrumentów można zaobserwować zarówno w perspektywie długookresowej, jak i w ciągu ostatniej dekady. Jeżeli chodzi o Polskę, bodźce podatkowe wspierające działalność B+R były do niedawna stosowane jedynie w bardzo ograniczonym zakresie. Instrument ten został udostępniony szerokiemu gronu podmiotów gospodarczych dopiero na początku 2016 r. Celem artykułu jest analiza interwencji państwa polegającej na wprowadzeniu bodźców podatkowych wspierających działalność B+R, w tym w szczególności odpowiedź na następujące pytania: (1) Kiedy państwo powinno podejmować interwencję za pomocą instrumentów polityki innowacyjnej? (2) Jakie czynniki zadecydowały o popularności i coraz większej hojności bodźców podatkowych wspierających działalność B+R? (3) Jakie były okoliczności i powody wprowadzenia ww. bodźców podatkowych w Polsce?
\end{abstract}

Słowa kluczowe: polityka innowacyjna, bodźce podatkowe, działalność $B+R$, interwencja państwa, Polska

1 Kolegium Ekonomiczno-Społeczne, Instytut Studiów Międzynarodowych, Zakład Bezpieczeństwa Międzynarodowego, Szkoła Główna Handlowa w Warszawie. 
Public intervention with the use of innovation policy instruments: the implementation of tax incentives as a way to increase R\&D in Poland

\begin{abstract}
Globally, tax incentives belong to the group of the most popular state intervention tools which are directed to support R\&D activities. From a historical perspective, the prevalence of $R \& D$ tax incentives has increased both in the long-run and also over the past decade. When it comes to Poland, until the beginning of 2016 R\&D tax incentives were used only to a very limited extent. Afterwards they became available to a wide range of entrepreneurs. The aim of the article is to analyze state interventions involving the introduction of R\&D tax incentives, and in particular to answer the following questions: (1) When should the state intervene with the use of innovation policy instruments? (2) What factors have determined the popularity and increasing generosity of R\&D tax incentives? (3) What were the circumstances and reasons for the introduction of R\&D tax incentives in Poland?
\end{abstract}

Keywords: innovation policy, tax incentives, R\&D activity, state intervention, Poland

Bodźce podatkowe, które mają na celu wsparcie rozwoju działalności badawczo-rozwojowej $(\mathrm{B}+\mathrm{R})$ są zaliczane do grona najpopularniejszych instrumentów polityki innowacyjnej. W 2017 r. instrumenty te były stosowane w 30 z 35 państw Organizacji Współpracy Gospodarczej i Rozwoju (Organization for Economic Co-operation and Development - OECD) (OECD, 2017). Ponadto środki wydatkowane na wsparcie działalności $\mathrm{B}+\mathrm{R}$ przy wykorzystaniu bodźców podatkowych stanowiły blisko połowę całkowitych wydatków, które ww. państwa przeznaczyły na stymulowanie działalności $\mathrm{B}+\mathrm{R}$ w sektorze prywatnym (ibidem) ${ }^{2}$. W ujęciu historycznym wzrost popularności omawianych instrumentów można zaobserwować zarówno w perspektywie długookresowej (tj. od lat 80. XX w.), jak i w ciągu ostatniej dekady (tj. w latach 2006-2015) (rysunek 1). Co więcej, wzrost znaczenia bodźców podatkowych jako instrumentów polityki innowacyjnej jest związany nie tylko z upowszechnieniem ich wykorzystania, ale również ze wzrostem hojności poszczególnych państw, jeżeli chodzi o skalę korzyści finansowych, jakie mogą osiągać podmioty gospodarcze w związku z wykorzystaniem tego typu instrumentów.

Jak widać na rysunku 1, bodźce podatkowe wspierające działalność $B+R$ to instrument wykorzystywany zarówno przez państwa zaliczane do grona tzw. liderów

\footnotetext{
2 Dane z 2015 r. dotyczące państw OECD.
} 
innowacyjności (np. Holandia, Wielka Brytania, Stany Zjednoczone, Dania), jak i państwa zajmujące dość odległe pozycje w rankingu innowacyjności (np. Rosja, Chile, Meksyk) (Cornell University, 2018) ${ }^{3}$. Podobnie instrument ten jest stosowany przez państwa reprezentujące różne modele narodowych systemów innowacji (NSI), np.: Holandia, Irlandia - dynamiczny model NSI; Korea Południowa, Wielka Brytania, Francja, Włochy, Japonia, Stany Zjednoczone, Kanada, Norwegia, Australia, Austria, Nowa Zelandia, Hiszpania - stabilnie funkcjonujący model NSI; Dania, Belgia - nierównomiernie rozwinięty model NSI; Portugalia, Grecja, Czechy, Słowenia, Słowacja, Litwa, Łotwa, Polska, Węgry - doganiający model NSI; Rosja, Chile, Republika Południowej Afryki, Chiny, Brazylia, Meksyk, Turcja - niezbilansowany model NSI (Weresa, 2012).

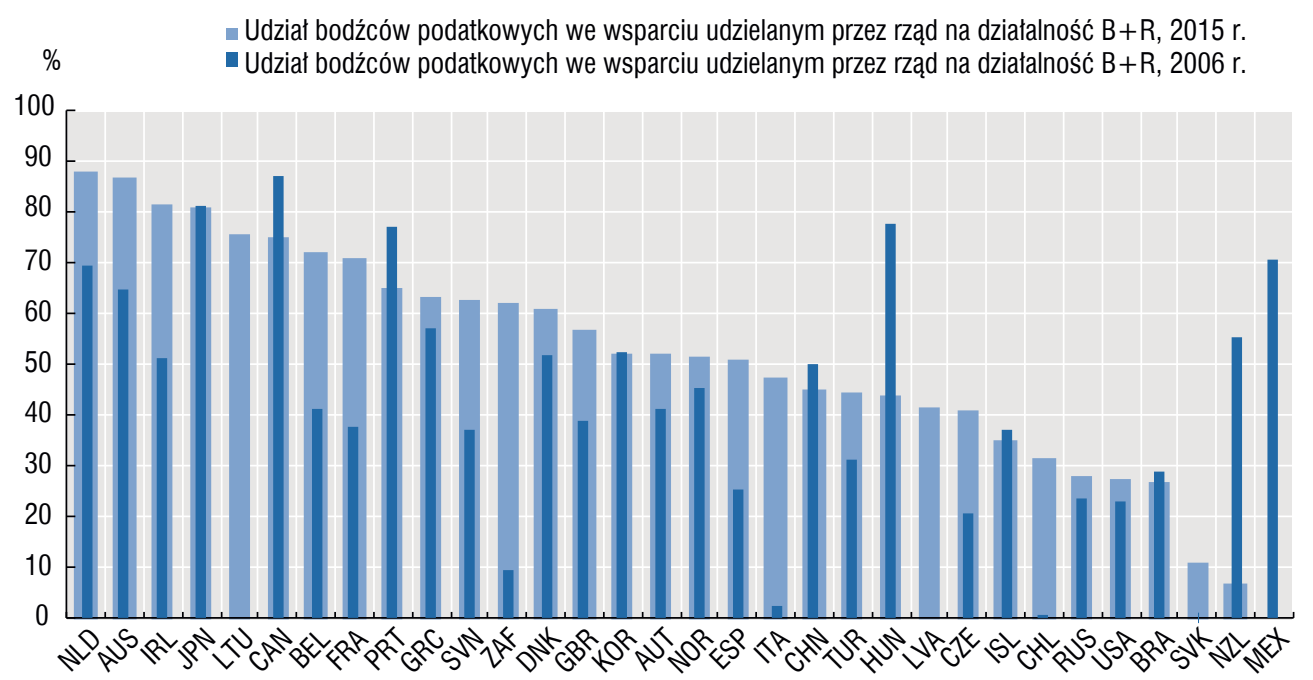

Rysunek 1. Zmiana poziomu wsparcia działalności badawczo-rozwojowej w sektorze prywatnym przy wykorzystaniu instrumentów bezpośrednich i bodźców podatkowych w 2006 r. i 2015 r.*

AUS - Australia, AUT - Austria, BEL - Belgia, BRA - Brazylia, CAN - Kanada, CHL-Chile, CHN - Chiny, CZE - Czechy, DNK - Dania, ESP - Hiszpania, FRA - Francja, GBR - Wielka Brytania, GRC - Grecja, HUN - Węgry, IRL - Irlandia, ISL - Islandia, ITA - Włochy, JPN - Japonia, KOR - Korea Południowa, LTU - Litwa, LVA - Łotwa, MEX - Meksyk, NLD - Holandia, NOR - Norwegia, NZL - Nowa Zelandia, PRT - Portugalia, RUS - Rosja, SVK - Słowacja, SVN - Słowenia, TUR - Turcja, USA - Stany Zjednoczone, ZAF - Republika Południowej Afryki.

${ }^{\star}$ Dane przedstawione jako procent całkowitego wsparcia.

Źródło: OECD (2017: 157).

3 W rankingu Global Innovation Index 2018 wymienione państwa zajmują następujące pozycje: Holandia - 2, Wielka Brytania - 4, Stany Zjednoczone - 6, Dania - 8, Rosja - 46, Chile - 47, Meksyk - 56 (Cornell Univeristy, 2018). 
Polska bodźce podatkowe wspierające działalność $\mathrm{B}+\mathrm{R}$ do niedawna wykorzystywała jedynie w bardzo ograniczonym zakresie (co zostanie opisane $w$ dalszej części artykułu). Instrument ten został udostępniony szerokiemu gronu podmiotów gospodarczych dopiero na początku 2016 r. Tym samym Polska, mimo tendencji do wzorowania się na rozwiązaniach stosowanych (w ramach polityki innowacyjnej) w innych państwach, nie do końca wpisuje się w ogólnoświatowy trend, jeżeli chodzi o wykorzystanie ww. instrumentów.

Celem tego artykułu jest analiza interwencji państwa polegającej na wprowadzeniu bodźców podatkowych wspierających działalność $\mathrm{B}+\mathrm{R}, \mathrm{w}$ tym w szczególności odpowiedź na pytania: (1) Kiedy państwo powinno podejmować interwencję za pomocą instrumentów polityki innowacyjnej? (2) Jakie czynniki zadecydowały o popularności i coraz większej hojności bodźców podatkowych wspierających działalność $\mathrm{B}+\mathrm{R}$ ? (3) Jakie były okoliczności i powody wprowadzenia ww. bodźców podatkowych w Polsce? W przypadku pytania pierwszego przeprowadzona analiza dotyczy koncepcji teoretycznych interwencji państwa. W celu odpowiedzi na pytanie drugie został przeprowadzony m.in. przegląd badań dotyczących efektywności stymulowania działalności $\mathrm{B}+\mathrm{R}$ za pomocą bodźców podatkowych, jak również przeanalizowano wpływ potencjalnych innych czynników, które mogły się przyczynić do wzrostu popularności omawianych instrumentów polityki innowacyjnej. Natomiast odpowiedź na pytanie trzecie obejmuje analizę przebiegu procesu legislacyjnego i rozwiązań o charakterze bodźców podatkowych wspierających działalność $B+R$, które zostały wprowadzone w Polsce, w tym analizę czynników uzasadniających interwencję państwa w omawianym obszarze.

\section{Teoretyczne koncepcje uzasadniające interwencje państwa za pomocą instrumentów polityki innowacyjnej}

Odpowiedź na pytanie, kiedy państwo powinno podejmować interwencję za pomocą instrumentów polityki innowacyjnej i tym samym ingerować w procesy tworzenia i dyfuzji innowacji, jest dość złożona. Od strony teoretycznej wykształciły się trzy główne nurty koncepcji uzasadniających interwencję państwa w ww. obszarze (Edler i in., 2016). Pierwszy z nich odwołuje się do ekonomii neoklasycznej i zakłada, że warunkiem koniecznym interwencji jest występowanie tzw. zawodności rynku (market failure), tj. sytuacji, w której mechanizm rynkowy nie działa poprawnie, tzn. nie prowadzi do efektywnej (w sensie Pareto) alokacji zasobów. Przyczyny nieprawidłowego działania mechanizmów rynkowych mogą być różne; z punktu widzenia polityki innowacyjnej jest to najczęściej brak bodźców do inwestowania w rozwój 
wiedzy (Lundvall, Borrás, 2007). Brak ww. bodźców oznacza, że mechanizm rynkowy nie odzwierciedla ( $w$ wystarczającym stopniu) poniesionych kosztów lub oczekiwanych zysków, co zazwyczaj jest spowodowane niedoskonałą konkurencją, asymetrią informacyjną, negatywnymi efektami zewnętrznymi czy też zawodnością mechanizmów koordynacyjnych (Mazzucato, Penna, 2014; Mazzucato, 2015). W świetle omawianego nurtu koncepcji uzasadniających interwencję państwa bardzo ważnym elementem działalności państwa jest analiza (tj. stałe monitorowanie) poprawności działania mechanizmów rynkowych. W przypadku występowania określonej zawodności rynku rola państwa polega najpierw na zidentyfikowaniu potencjalnych narzędzi, które mogą jej przeciwdziałać. Etap ten powinien objąć analizę wszystkich możliwych obszarów interwencji, takich jak: reforma instytucjonalna, finanse publiczne, bodźce podatkowe, zakupy rządowe, produkcja państwowa itd. (Hämäläinen, 2003). Innymi słowy, władze państwowe - w obliczu konieczności przeciwdziałania określonej zawodności rynku - powinny przeanalizować potencjalne następstwa każdego z możliwych obszarów i narzędzi interwencji w celu podjęcia decyzji czy (i ewentualnie w jaki sposób) interweniować. Jeżeli żadne z dostępnych narzędzi nie jest w stanie przeciwdziałać danej zawodności rynku - interwencji należy zaniechać. Jeżeli natomiast istnieją instrumenty pozwalające na poprawę działania mechanizmu rynkowego - powinny zostać wybrane i wdrożone te z nich, które są (lub wydają się potencjalnie) najskuteczniejsze. Tego typu analiza poprawności działania mechanizmów rynkowych powinna być przeprowadzana w sposób regularny (co de facto oznacza proces niemal ciągły), ponieważ mocne i słabe strony różnych rozwiązań organizacyjnych z biegiem czasu ulegają zmianie. Najważniejszym zasobem, niezbędnym do podjęcia właściwej decyzji odnośnie do potrzeby i rodzaju interwencji państwa, jest wiedza na temat zalet i wad wszystkich alternatywnych rozwiązań w sektorze prywatnym, państwowym i trzecim sektorze, w danym kontekście społeczno-gospodarczym; bez takiej wiedzy nie można podjąć racjonalnej decyzji w zakresie odpowiedniej interwencji lub reformy regulacyjnej (ibidem). Warto też podkreślić, że wskazana powyżej wiedza jest bardzo ważnym zasobem bez względu na nurt, z którego wywodzi się dana koncepcja interwencji państwa w ramach polityki innowacyjnej.

Analizowany nurt koncepcji interwencji państwa pozostaje w ścisłym związku ze sposobem postrzegania procesów innowacyjnych przez neoklasyków ekonomii. Po pierwsze, należący do tego nurtu ekonomiści pierwotnie zawężali procesy innowacyjne do prowadzenia badań oraz do powstałych w ich wyników wynalazków. Po drugie, według neoklasyków procesy innowacyjne są procesami o charakterze liniowym, składającymi się z określonej sekwencji następujących po sobie etapów (faz), w przypadku których etap związany z prowadzeniem badań niemal automatycznie przechodzi w fazę wytwarzania nowych produktów (a pytanie: w jaki sposób 
wyniki działalności B+R można spożytkować do stworzenia produktów, które będą mogły zostać wykorzystane $\mathrm{w}$ gospodarce, $\mathrm{tj}$. $\mathrm{z}$ sukcesem wprowadzone na rynek? - pozostaje bez odpowiedzi) (Rosenberg, 1982; 1994; Chaminade, Edquist, 2015).

Jak wcześniej wspomniano, podstawową zawodnością rynku z punktu widzenia polityki innowacyjnej jest najczęściej brak bodźców do inwestowania w rozwój wiedzy. Omawiane w artykule bodźce podatkowe, mające na celu wsparcie działalności $\mathrm{B}+\mathrm{R}$, mogą być stosowane w celu przeciwdziałania ww. zawodności. Jednak wsparcie finansowe, jakie otrzymują przedsiębiorcy dzięki interwencji państwa polegającej na wprowadzeniu bodźców podatkowych, często nie jest czynnikiem wystarczającym do tego, aby podmioty gospodarcze, które są potencjalnie zainteresowane prowadzeniem działalności $\mathrm{B}+\mathrm{R}$, podjęły taką działalność. Ich skłonność w tym zakresie może ograniczać fakt, że innowacje wykazują tendencję do szybkiego przekształcania się w dobra publiczne. Proces ten, mimo niewątpliwych korzyści społecznych, pozbawia innowatora możliwości generowania zysków adekwatnych do poniesionego ryzyka oraz nakładów i - w efekcie - pozbawia go bodźców finansowych do prowadzenia działalności innowacyjnej. Powyższy problem jest rozwiązywany za pomocą instrumentów mających na celu ochronę własności intelektualnej. Użycie tych instrumentów wymaga od państwa właściwego wyważenia korzyści płynących z utworzenia systemu umożliwiającego innowatorom osiągnięcie znacznych zysków (czyli takiego, który pobudza działalność innowacyjną) w stosunku do korzyści wynikających z szybszej dyfuzji innowacji (która przynosi większe korzyści makroekonomiczne). Literatura przedmiotu tworzy w tym względzie pojęcie tzw. reżimu zawłaszczenia (appropriability regime), odnoszące się do wszystkich czynników otoczenia mających wpływ na możliwości inwestora w zakresie pozyskania zysków generowanych przez wprowadzoną przez niego innowację (Stryjek, 2015).

Opisany powyżej problem pokazuje jedną ze słabości neoklasycznej koncepcji interwencji państwa w sytuacji pojawienia się zawodności rynku. Z jednej strony bowiem jako zawodność rynku traktowana jest asymetria informacyjna. $Z$ drugiej strony natomiast innowacje powstają najczęściej jako owoc asymetrii informacyjnej i prowadzą do dalszego jej pogłębienia. Z uwagi na skłonność innowacji do przekształcania się w dobra publiczne (i demotywujące konsekwencje tego procesu z punktu widzenia innowatorów) interwencja państwa polegająca na przeciwdziałaniu asymetrii informacyjnej nie jest pożądana. W zamian władze państwowe najczęściej sięgają po instrumenty mające na celu ochronę własności intelektualnej, które uniemożliwiają innym podmiotom komercyjne wykorzystanie objętych ochroną informacji ${ }^{4}$.

4 Warto w tym miejscu zaznaczyć, że systemy ochrony własności intelektualnej nie są rozwiązaniem idealnym i nie wszyscy innowatorzy chcą z nich korzystać. Ochrona danego rozwiązania (np. wynalazku) 
Drugi nurt koncepcji uzasadniających interwencję państwa w obszarze polityki innowacyjnej wywodzi się z ekonomii ewolucyjnej i odwołuje się do teorii systemów innowacji (SI). W ujęciu systemowym innowacje powstają w wyniku złożonych, nieliniowych procesów, $\mathrm{w}$ których przedsiębiorstwa wchodzą $\mathrm{w}$ interakcję $\mathrm{z}$ różnego typu organizacjami (np. jednostkami badawczymi, klientami, władzami państwowymi, podmiotami finansowymi itd.) oraz instytucjami ( $t j$. regulacjami prawnymi, normami kulturowymi itd. $)^{5}$; w przebiegu ww. procesów bardzo ważna jest wzajemność oddziaływania oraz mechanizmy umożliwiające przepływ informacji zwrotnych (Freeman, 1988; Lundvall, 1992; Nelson, 1993; Edquist, 1997; Klein i in., 2005). Koncepcje wywodzące się z tego nurtu całkowicie „odcinają się” od neoklasycznych założeń dotyczących zrównoważonego rynku i potrzeby interwencji państwa jedynie w sytuacji zawodności jego działania. W ujęciu systemowym potrzeba interwencji państwa jest uwarunkowana pojawieniem się problemów związanych $\mathrm{z}$ funkcjonowaniem systemu (tzw. problemów systemowych), przy czym analiza poprawności działania systemu ukierunkowana jest bardziej na zachodzące w nim procesy (wyniki prowadzonych działań) niż poszczególne jego elementy (Edquist, 2011). Co ważne, ocena poprawności działania systemu innowacji (czy też jego części) nie jest dokonywana w odniesieniu do stanu/działania optymalnego. Innymi słowy, z punktu widzenia teorii SI pojęcie optymalności zupełnie traci na znaczeniu, tj. nie znajduje zastosowania. W przypadku omawianego wcześniej nurtu ekonomii neoklasycznej zawodność rynku można zidentyfikować i/lub opisać poprzez porównanie stanu faktycznego ze stanem optymalnym (equilibrium). W przypadku ekonomii ewolucyjnej i teorii SI przyjmuje się, że system nigdy nie osiąga stanu optymalnego. W związku z powyższym nie jest możliwe określenie, jak taki optymalny system działa czy też jak jest zbudowany, a tym samym nie da się porównać systemu rzeczywistego z systemem optymalnym (Chaminade, Edquist, 2015). Ewentualna interwencja państwa jest reakcją na problem systemowy zidentyfikowany w wyniku porównania danego systemu $\mathrm{z}$ innymi istniejącymi systemami.

Trzeci nurt koncepcji uzasadniających interwencję państwa w ramach polityki innowacyjnej odwołuje się do idei, wedle której nauka i innowacje mogą (i powinny)

wymaga bowiem czasu, pociąga za sobą koszty oraz - co ważne - wymusza dokładne opisanie tego, co ochronie ma podlegać. Taki dokładny opis często pomaga konkurentom wprowadzić nieco zmienione (a więc niepodlegające ochronie) rozwiązanie. Poza tym, innowator jest zmuszony opóźnić (do momentu uzyskania ochrony) wprowadzenie swojego produktu na rynek. W związku z powyższym niektóre podmioty gospodarcze świadomie rezygnują z ubiegania się o ochronę własności intelektualnej; w zamian - starają się szybko wprowadzić produkt na rynek i maksymalizować jego sprzedaż, zanim konkurenci skopiują dany pomysł.

5 Podział elementów systemu innowacji na instytucje i organizacje nawiązuje do tzw. utylitarystycznej wersji nowego instytucjonalizmu (określanej mianem neoinstytucjonalizmu), którego głównym reprezentantem jest Douglass C. North. 
przyczyniać się do wypełniania misji i realizacji wyzwań społecznych (Edler i in., 2016). W świetle koncepcji należących do tego nurtu podstawowym obowiązkiem władz państwowych jest (1) wyznaczanie kierunku innowacyjnego rozwoju państwa w sposób umożliwiający zaspokojenie zarówno potrzeb samego państwa (dotyczących np. obrony, bezpieczeństwa itd.), jak i jego obywateli (w zakresie np. ochrony zdrowia, edukacji itd.), jak również (2) podejmowanie ryzyka i pomoc w tworzeniu nowych, pożądanych społecznie rynków (Mazzucato, 2015). Interwencja państwa za pomocą narzędzi polityki innowacyjnej sprowadza się w tym wypadku do wspierania inicjatyw, działań czy też podmiotów, które służą realizacji wskazanych powyżej celów. Polityka innowacyjna, która jest nastawiona na wypełnienie określonej misji społecznej, przybiera postać polityki horyzontalnej (ponadsektorowej) i wymaga (w bardzo dużym zakresie) koordynacji z polityką państwa prowadzoną w innych obszarach. Interwencje państwa w ramach tak prowadzonej polityki innowacyjnej są zazwyczaj podejmowane przy wykorzystaniu szerokiego wachlarza narzędzi interwencji.

\section{Bodźce podatkowe wspierające działalność badawczo-rozwojową jako popularny instrument polityki innowacyjnej}

Popularność danego instrumentu polityki państwa pozostaje najczęściej w ścisłym związku z jego efektywnością oraz zaletami i wadami stosowania. Bodźce podatkowe, które stymulują działalność $\mathrm{B}+\mathrm{R}$, nie są w tym względzie odosobnione, niemniej zarówno analiza ich efektywności, jak i bilans zalet i wad tych instrumentów zdają się jedynie częściowo wyjaśniać ich bardzo dużą i stale rosnącą popularność.

Przeprowadzone dotychczas badania nad efektywnością omawianych bodźców podatkowych w większości przypadków potwierdzają efektywność tych instrumentów (Elschner i in., 2011) ${ }^{6}$. Niemniej wykazywany w badaniach poziom efektywności ww. bodźców zdaje się być porównywalny z efektywnością instrumentów wspierających działalność $\mathrm{B}+\mathrm{R}$ w sposób bezpośredni - tj. na przykład grantów przyznawanych na realizację projektów badawczo-rozwojowych. Bardzo dobrze obrazują to badania przeprowadzone przez B. Halla i J. Van Reenena $(2000)^{7}$, w świetle których ulga

6 Należy pamiętać, że zróżnicowanie wyników badań może być w przypadku omawianych bodźców podatkowych konsekwencją różnych czynników, w tym zwłaszcza przyjętego sposobu ewaluacji czy też tego, w jaki sposób dany instrument został zaprojektowany. Więcej informacji na temat wpływu cech danego instrumentu na jego efektywność: Elschner i in. (2015).

7 Autorzy, poza własnymi badaniami, prezentują również wartościowy przegląd innych badań nad efektywnością bodźców podatkowych wspierających działalność $\mathrm{B}+\mathrm{R}$, zwracając uwagę na ewentualne słabe strony zastosowanych metod badawczych. 
podatkowa na działalność $\mathrm{B}+\mathrm{R}$ ( $R \& D$ tax credit) $\mathrm{w}$ wysokości 1 dolara stymuluje (dodatkowe) wydatki inwestycyjne na działalność $\mathrm{B}+\mathrm{R}$ w wysokości 1 dolara (Hall, Van Reenen, 2000). Wynik powyższych badań z jednej strony pokazuje, że powstała na skutek wprowadzenia ww. ulgi strata podatkowa przynosi zamierzony efekt, gdyż środki, które nie trafiły do budżetu państwa $\mathrm{w}$ postaci podatków zostają przekierowane na dodatkową działalność $\mathrm{B}+\mathrm{R}$. $\mathrm{Z}$ drugiej strony natomiast widać, że poddana badaniu ulga podatkowa na $\mathrm{B}+\mathrm{R}$ nie powinna być postrzegana jako narzędzie bardziej efektywne niż instrumenty bezpośrednie (np. niż wspomniane wcześniej granty na realizację projektów $\mathrm{B}+\mathrm{R}$ ). Gdy zastanowimy się, jaka jest relacja wielkości straty budżetowej do wartości inwestycji w działalność $\mathrm{B}+\mathrm{R}$ w przypadku grantu badawczego, wówczas okazuje się, że sytuacja wygląda wręcz analogicznie, jak miało to miejsce w przypadku ww. ulgi podatkowej, tj.: 1 dolar pochodzący ze środków budżetowych, który zostaje przekazany określonemu podmiotowi w postaci grantu badawczego, prowadzi do wydatkowania na działalność $\mathrm{B}+\mathrm{R}$ środków o wartości 1 dolara. Ponadto, koniecznie należy w tym miejscu podkreślić, że istnieją także badania wskazujące na niższą efektywność bodźców podatkowych wspierających działalność B+R niż przytoczone powyżej badania B. Halla i J. Van Reenena (Yang i in., 2012; European Comission, 2014). W związku z tym należy uznać, że efektywność omawianych bodźców podatkowych jest co najwyżej porównywalna z efektywnością innych (tj. bezpośrednich) instrumentów polityki innowacyjnej.

W sytuacji, gdy o popularności danego instrumentu nie przesądza jego efektywność, warto przyjrzeć się wadom i zaletom stosowania tego narzędzia i porównać je $z$ alternatywnymi rozwiązaniami. Jeżeli chodzi o bodźce podatkowe wspierające działalność $\mathrm{B}+\mathrm{R}$ i alternatywne do nich instrumenty bezpośrednie, na korzyść bodźców podatkowych przemawia fakt, że przedsiębiorstwa, dzięki obecności na rynku, posiadają lepszą wiedzę (czy chociażby intuicję) na temat projektów, które potencjalnie mogą odnieść sukces, w związku z czym podejmują trafniejsze decyzje inwestycyjne (niż decydenci kwalifikujący projekty do wsparcia bezpośredniego). Ponadto, zaletą bodźców podatkowych są niższe niż w przypadku instrumentów bezpośrednich koszty administracyjne. Jednak z drugiej strony - stymulowanie działalności B+R za pomocą instrumentów bezpośrednich daje możliwość wsparcia projektów o wyższej społecznej stopie zwrotu (Bérubé, Mohnen, 2009: 209), co można uznać za pewien rodzaj przeciwwagi w stosunku do przedstawionych wcześniej zalet pobudzania działalności B+R za pomocą bodźców podatkowych. Ponadto stosowanie ww. bodźców podatkowych jest obarczone również następującymi rodzajami ryzyka (Carvalho, 2012; OECD, 2014; Busom i in. 2014):

- większym (niż w przypadku instrumentów bezpośrednich) ryzykiem wsparcia projektów, które w przypadku braku ww. wsparcia i tak zostałyby zrealizowane, 
- ryzykiem nadużycia polegającym na klasyfikowaniu przez przedsiębiorstwa jako koszty działalności $\mathrm{B}+\mathrm{R}$ również innych ponoszonych kosztów,

- ryzykiem związanym z wysokim poziomem nieprzewidywalności odnośnie do wielkości „straty podatkowej”, będącej konsekwencją wprowadzenia bodźców podatkowych, co oznacza osłabienie możliwości kontroli wpływów budżetowych. W wyjaśnianiu przyczyn popularności bodźców podatkowych wspierających działalność $\mathrm{B}+\mathrm{R}$ pomocne okazują się nie tylko indywidualne cechy ww. instrumentów, ale również wiele innych czynników, w tym w szczególności zmiany zachodzące w środowisku międzynarodowym. Procesy, takie jak (1) postępująca globalizacja (i towarzysząca jej liberalizacja handlu), (2) wzrost znaczenia (i nasilenie) przepływów bezpośrednich inwestycji zagranicznych (BIZ), (3) procesy integracji regionalnej oraz (4) wzrost roli innowacji w rozwoju gospodarczym państw, bez wątpienia przyczyniły się do szerszego zastosowania omawianych instrumentów w wielu państwach na świecie. Z jednej strony, proces globalizacji i procesy regionalnej integracji państw doprowadziły do wzrostu roli bodźców inwestycyjnych ukierunkowanych na przyciągnięcie BIZ. Z drugiej strony, globalizacja (i towarzysząca jej liberalizacja handlu) spowodowała, że zmniejszyło się znaczenie wielkości rynku krajowego jako czynnika determinującego napływ BIZ do danej gospodarki. W rezultacie nawet małe państwa zyskały realną szansę na przyciągnięcie BIZ, uwarunkowaną m.in. wprowadzeniem wystarczająco atrakcyjnych bodźców inwestycyjnych. Oznacza to, że liczba państw konkurujących o napływ BIZ się zwiększyła, a tym samym nasiliła się konkurencja. Co więcej, państwa często starają się przyciągnąć BIZ do sektora badawczo-rozwojowego $\mathrm{z}$ uwagi na potencjalny transfer wiedzy $\mathrm{i} / \mathrm{lub}$ technologii. $Z$ tego punktu widzenia bodźce podatkowe wspierające działalność $\mathrm{B}+\mathrm{R}$ stają się instrumentem mogącym niejako odgrywać podwójną rolę, tj. nie tylko zachęcać przedsiębiorstwa krajowe do prowadzenia działalności $B+R$, ale również pełnić rolę bodźca wspierającego napływ BIZ do sektora badawczo-rozwojowego danego państwa.

Ponadto rozpowszechnienie bodźców podatkowych wspierających działalność $\mathrm{B}+\mathrm{R}$ rodzi ryzyko pojawienia się niekorzystnego (z punktu widzenia wpływów budżetowych z podatków) zjawiska międzypaństwowej konkurencji podatkowej. Globalizacja i procesy regionalnej integracji państw w gospodarce światowej sprawiły, że przedsiębiorstwom jest łatwiej przenieść swoją działalność za granicę w sytuacji, gdy koszty jej prowadzenia $\mathrm{w}$ państwie docelowym są niższe. $\mathrm{Z}$ tego punktu widzenia wprowadzenie ww. bodźców podatkowych może też pełnić rolę czynnika zapobiegającego przenoszeniu przez krajowe przedsiębiorstwa działalności $\mathrm{B}+\mathrm{R}$ poza granice państwa.

Poza tym proces integracji regionalnej w Europie, który doprowadził do utworzenia Unii Europejskiej, przyczynił się do szerszego wykorzystania przez państwa 
członkowskie UE instrumentów wspierających działalność $\mathrm{B}+\mathrm{R}$ (w tym m.in. omawianych bodźców podatkowych) za sprawą wytycznych polityki innowacyjnej, ustanowionych na szczeblu ponadnarodowym. W 2000 r. Unia Europejska przyjęła strategię lizbońską, w której został wyznaczony ambitny cel w postaci wzrostu wydatków państw członkowskich na działalność $\mathrm{B}+\mathrm{R}$ do poziomu 3 proc. $\mathrm{PKB}$ (dodatkowo przyjęto zalecenie, aby dwie trzecie ww. wydatków stanowiły wydatki sektora prywatnego). Mimo że cel ten okazał się w większości przypadków niemożliwy do osiągnięcia, niewątpliwie stanowił impuls do szerszego wykorzystania bodźców podatkowych wspierających działalność $\mathrm{B}+\mathrm{R}$ przez państwa członkowskie UE. Co więcej, strategia „Europa 2020”, która zastąpiła strategię lizbońską, ponownie ustanowiła pożądany limit inwestycji państw członkowskich UE w działalność B+R na poziomie 3 proc. $\mathrm{PKB}$, podkreślając jednocześnie, że inwestycje prywatne w tym zakresie są lepsze od inwestycji publicznych. Przyjęcie (i wdrażanie) powyższej strategii stanowi więc kolejny impuls do stosowania przez państwa członkowskie UE narzędzi wspierających działalność $\mathrm{B}+\mathrm{R} w$ sektorze prywatnym, a tym samym przyczynia się do popularyzacji stosowanych w tym względzie bodźców podatkowych.

\section{Wprowadzenie bodźców podatkowych wspierających działalność badawczo-rozwojową w Polsce}

Minione półtorej dekady to okres intensywnego rozwoju polityki innowacyjnej w Polsce. Bodźcem, który silnie zmobilizował Polskę do podjęcia działań w ww. zakresie było członkostwo w Unii Europejskiej i związana z nim konieczność dostosowania się do wytycznych polityki prowadzonej przez UE na szczeblu ponadnarodowym (Stryjek, 2015: 69). Duże znaczenie w tym względzie odegrał czynnik finansowy, tzn. możliwość wsparcia prowadzonych przez państwo interwencji środkami finansowymi, które zostały przydzielone Polsce jako członkowi UE. Badania przeprowadzone po przystąpieniu Polski do Unii Europejskiej wykazywały, że brak środków finansowych stanowił - w opinii polskich przedsiębiorców - najpoważniejszą barierę innowacyjnego rozwoju ich przedsiębiorstw (Starczewska-Krzysztoszek, 2007). Uzyskanie przez Polskę dostępu do znacznych środków finansowych pochodzących z funduszy strukturalnych UE, których duża część mogła (a nawet musiała) zostać wydatkowana na wsparcie innowacyjności przedsiębiorstw i gospodarki, poniekąd idealnie „wpasowało się” w zidentyfikowane na rynku zapotrzebowanie. Okoliczności te sprawiły, że uwaga rządu (i władz samorządowych) została skierowana na politykę innowacyjną i działania wspierające rozwój narodowego systemu innowacji. Pozostał jednak problem właściwego doboru 
narzędzi interwencji i nieduże doświadczenie polskich decydentów (zwłaszcza na szczeblu samorządowym) w ww. zakresie.

Po wejściu do Unii Europejskiej Polska starała się wdrażać rozwiązania, które stosowane były w innych państwach członkowskich, korzystając (zgodnie z unijnymi zaleceniami) z tzw. wzorów najlepszych praktyk oraz stymulując rozwój narodowego systemu innowacji na wzór systemów występujących w państwach uznawanych za liderów innowacyjności. Choć nie można powiedzieć, aby zastosowanie strategii naśladowczej spełniło pokładane w niej oczekiwania, to kiedy analizuje się rozwój polityki innowacyjnej przez pryzmat tej strategii, zadziwiający może się wydawać fakt późnego wdrożenia w Polsce tak popularnych instrumentów, jakimi są bodźce podatkowe wspierające działalność $\mathrm{B}+\mathrm{R}$. Instrument ten został wprowadzony dla szerokiego grona podatników (tj. zarówno płatników podatku dochodowego od osób fizycznych, jak i podatku dochodowego od osób prawnych) dopiero w $2016 \mathrm{r}$.

Przed 2016 r. były stosowane dwa inne instrumenty o charakterze bodźców podatkowych, niemniej zostały one tak zaprojektowane, że ich wykorzystanie przez przedsiębiorców było niewielkie. Pierwszy ze wspomnianych powyżej instrumentów to tzw. ulga technologiczna (Ustawa..., 2005). Instrument ten umożliwiał odliczenie od podstawy opodatkowania podatkiem CIT połowy wydatków poniesionych na nabycie nowych (tj. stosowanych na świecie przez okres nie dłuższy niż 5 lat) technologii, czyli de facto wspierał transfer technologii, a nie własną działalność $\mathrm{B}+\mathrm{R}$ przedsiębiorstw. Warto tu dodać, że - przykładowo - w latach 2006-2011 z ulgi technologicznej skorzystały zaledwie 892 przedsiębiorstwa (Jasiński, 2013). Natomiast drugi z ww. instrumentów umożliwiał (docelowo) obniżenie podstawy opodatkowania podatkiem CIT niewielkiej grupie przedsiębiorstw, którym został przyznany status centrum badawczo-rozwojowego (CBR). Status CBR był nadawany według zasad określonych w Ustawie o niektórych formach wspierania działalności innowacyjnej z 2005 r. (a następnie w Ustawie o niektórych formach wspierania działalności innowacyjnej z 2008 r.), w drodze decyzji administracyjnej ministra właściwego do spraw gospodarki. Centra badawczo-rozwojowe uzyskały możliwość przeznaczania do 20 proc. swoich przychodów na tzw. fundusz innowacyjności, który był wliczany do kosztów ich działalności. Środki funduszu mogły być wykorzystywane na pokrywanie kosztów prowadzenia badań i prac rozwojowych oraz kosztów związanych z uzyskaniem patentu na wynalazek. W praktyce zainteresowanie uzyskaniem statusu CBR było niewielkie - na dzień 21 stycznia 2015 r. status taki posiadały zaledwie 34 podmioty gospodarcze (Uzasadnienie..., 2015). Co więcej, często o status CBR ubiegały się dawne państwowe instytuty badawczo-rozwojowe, przekształcone w spółki prawa handlowego, które raczej nie miały być główną grupą docelową z punktu widzenia intencji ustawodawcy. 
Powszechnie dostępny (tj. niewymagający uzyskania wcześniej żadnego specjalnego statusu) instrument podatkowy wspierający działalność B+R został wprowadzony w Polsce na mocy Ustawy z dnia 25 września 2015 r. o zmianie niektórych ustaw w związku ze wspieraniem innowacyjności (Ustawa..., 2015). Dzięki ww. zmianom prawnym podmioty gospodarcze uzyskały możliwość skorzystania z ulgi podatkowej, tj. możliwość odliczenia od podstawy opodatkowania kosztów uzyskania przychodów poniesionych na działalność $B+R$. Co ważne, takie same zmiany dotyczące ulgi na działalność $\mathrm{B}+\mathrm{R}$ wprowadzono w Ustawie z dnia 26 lipca $1991 \mathrm{r}$ o podatku dochodowym od osób fizycznych oraz Ustawie z dnia 15 lutego 1992 r. o podatku dochodowym od osób prawnych.

W świetle problemów omawianych w niniejszym artykule pojawia się pytanie o czynniki uzasadniające interwencję państwa polegającą na wprowadzeniu ww. ulgi podatkowej na działalność $B+R$. Od strony teoretycznej, w przypadku stymulowania przez państwo działalność $\mathrm{B}+\mathrm{R}$, potrzebę interwencji mogły wskazać zarówno koncepcje wywodzące się z ekonomii neoklasycznej, jak i z ekonomii ewolucyjnej. Z jednej strony można bowiem w takiej sytuacji mówić o istnieniu zawodności rynku, tj. braku wystarczających bodźców do inwestowania przez podmioty gospodarcze w badania i rozwój. $Z$ drugiej strony natomiast decyzję dotyczącą interwencji można podjąć np. na podstawie porównania wielkości inwestycji $w$ działalność $B+R$ z wynikami osiąganymi w tym zakresie przez inne państwa. A w jaki sposób faktycznie argumentowano ww. interwencję w Polsce? Gdy analizuje się uzasadnienie, jakie wraz z projektem Ustawy o zmianie niektórych ustaw w związku ze wspieraniem innowacyjności (Uzasadnienie..., 2015) prezydent Bronisław Komorowski przedstawił Sejmowi RP, zdecydowanie widać, że w Polsce - zgodnie z panującą w UE ogólną tendencją (European Comission, 2002) - decyzja o potrzebie interwencji państwa była uwarunkowana oceną porównawczą wyników osiąganych przez narodowy system innowacji z wynikami dotyczącymi systemów innych państw (w tym też zobowiązaniem do osiągnięcia określonego poziomu wskaźnika wydatków na działalność $\mathrm{B}+\mathrm{R}$, wyznaczonego $\mathrm{w}$ ramach wytycznych polityki UE). $\mathrm{W}$ ww. uzasadnieniu pojawiły się następujące argumenty:

„Celem dla Polski w ramach strategii Europa 2020 jest wzrost łącznych nakładów na $\mathrm{B}+\mathrm{R}$ do poziomu 1,7\% PKB w 2020 roku. Zrealizowanie tego wyzwania oznacza intensyfikację prac $\mathrm{B}+\mathrm{R}$, przede wszystkim w sektorze przedsiębiorstw. System wspierania innowacji w Polsce opiera się głównie na dotacjach, które wspierają transfer i absorpcję technologii. Istniejące zaś bodźce podatkowe dla $\mathrm{B}+\mathrm{R}$ ocenia się jako nieskuteczne w promowaniu wewnętrznych prac $\mathrm{B}+\mathrm{R} w$ sektorze prywatnym. Dodatkowo dane pokazują wykorzystanie ich głównie przez duże przedsiębiorstwa. (...) W 2014 r. Polska w unijnym Rankingu Innowacyjności zajęła odległe 25. miejsce, 
ostatnie w grupie tzw. „umiarkowanych innowatorów”, osiągając 50,5\% średniego ogólnego wskaźnika innowacyjności dla krajów UE. Również w Globalnym Rankingu Konkurencyjności na lata 2014-2015 pod względem innowacyjności Polska zajmuje 72 miejsce na świecie. (...) Nowa perspektywa finansowa na lata 2014-2020 w ramach programów operacyjnych stwarza olbrzymie możliwości na prowadzenie $\mathrm{B}+\mathrm{R}(\ldots)$ oraz daje szansę podniesienia konkurencyjności mikro, małych i średnich przedsiębiorstw. Jednak środki UE z czasem zostaną wykorzystane, a stworzenie skutecznego modelu wspierania innowacyjności to długi proces (...). Z tego powodu już teraz należy zaproponować bardziej efektywną preferencję podatkową na B+R" (Uzasadnienie..., 2015).

Bardzo ważną cechą nowo wprowadzanego instrumentu podatkowego była możliwość zaliczenia do kosztów uzyskania przychodów kosztów szeroko rozumianej działalności $\mathrm{B}+\mathrm{R}$, tj. kosztów badań naukowych i prac rozwojowych niezależnie od ich wyników (obowiązujące wcześniej przepisy podatkowe umożliwiały zaliczenie do kosztów uzyskania przychodów wyłącznie kosztów prac rozwojowych i to tylko takich, które zostały zakończone wynikiem pozytywnym). Jeżeli chodzi natomiast o mechanizm i zakres wprowadzonej ulgi podatkowej, przyjęta ostatecznie ustawa bardzo różniła się pod tym względem od pierwotnego projektu.

Ustawa wprowadziła katalog tzw. kosztów kwalifikowanych, tj. kosztów działalności B+R, które mogą podlegać odliczeniu. Koszty kwalifikowane objęły m.in.: koszty wynagrodzeń; koszty nabycia materiałów i surowców bezpośrednio związanych z prowadzoną działalnością badawczo-rozwojową; odpłatne korzystanie $\mathrm{z}$ aparatury naukowo-badawczej wykorzystywanej wyłącznie w prowadzonej działalności badawczo-rozwojowej; odpisy amortyzacyjne od środków trwałych oraz wartości niematerialnych i prawnych wykorzystywanych w prowadzonej działalności badawczo-rozwojowej; koszty ekspertyz, opinii, usług doradczych oraz koszty nabycia wyników badań naukowych, świadczonych lub wykonywanych na podstawie umowy przez jednostkę naukową. W ramach wprowadzonej ulgi podatkowej wszyscy przedsiębiorcy uzyskali możliwość odliczenia 30 proc. kosztów wynagrodzeń. Jeżeli chodzi natomiast o pozostałe koszty kwalifikowane - mikro, małe oraz średnie przedsiębiorstwa mogły odliczyć 20 proc., a pozostali przedsiębiorcy 10 proc. ww. kosztów.

W kolejnych latach uchwalone zostały dalsze zmiany, jeżeli chodzi o zakres i wielkość możliwych odpisów w ramach omawianej ulgi podatkowej, tj.:

- Na początku stycznia 2017 r. weszła w życie Ustawa z dnia 4 listopada 2016 r. o zmianie niektórych ustaw określających warunki prowadzenia działalności innowacyjnej (Ustawa..., 2016), która rozszerzyła katalog kosztów kwalifikowanych o koszty związane z ochroną własności intelektualnej (m.in. koszty uzyskania 
i utrzymania patentu, prawa ochronnego na wzór użytkowy itd.) i uatrakcyjniła zakres możliwych odliczeń; mikro, małe i średnie przedsiębiorstwa zyskały wówczas możliwość odliczenia od podstawy opodatkowania 50 proc. wszystkich rodzajów kosztów kwalifikowanych, a duże przedsiębiorstwa - 50 proc. kosztów wynagrodzeń i 30 proc. pozostałych kosztów. Ponadto nowo utworzone przedsiębiorstwa, które poniosły stratę lub wygenerowały dochód niższy niż przysługujące im za dany rok odliczenie, zyskały możliwość zwrotu kwoty odpowiadającej iloczynowi nieodliczonej ulgi $\mathrm{B}+\mathrm{R}$ i stawki podatku.

- Następnie od stycznia 2018 r., na mocy Ustawy z dnia 9 listopada 2017 r. o zmianie niektórych ustaw w celu poprawy otoczenia prawnego działalności innowacyjnej (Ustawa..., 2017), katalog kosztów kwalifikowanych został poszerzony o kolejne kategorie kosztów - m.in. o koszty wynagrodzeń wypłacanych na podstawie umowy zlecenia lub umowy o dzieło i koszty nabycia sprzętu specjalistycznego niebędącego środkiem trwałym (wykorzystywanego bezpośrednio w prowadzonej działalności $B+R)$. Ponadto, znacznie wzrósł poziom odliczeń w ramach ulgi podatkowej, tj. wszyscy przedsiębiorcy prowadzący prace $B+R$ (bez względu na wielkość przedsiębiorstwa) mogą od tego momentu odliczać od podstawy opodatkowania 100 proc. wszystkich kosztów kwalifikowanych; dodatkowo przedsiębiorcy posiadający status CBR zyskali możliwość odliczenia od podstawy opodatkowania aż 150 proc. kosztów kwalifikowanych (wyjątek stanowią tu duże przedsiębiorstwa, w przypadku których możliwość odliczenia takich kosztów, jak koszty utrzymania patentu, prawa ochronnego na wzór użytkowy i prawa $\mathrm{z}$ rejestracji wzoru przemysłowego została utrzymana na poziomie 100 proc.).

Bodźce podatkowe wspierające rozwój działalności $\mathrm{B}+\mathrm{R}$ to instrumenty polityki innowacyjnej, których wykorzystanie bardzo dobrze wpisuje się we wszystkie główne nurty koncepcji uzasadniających potrzebę interwencji państwa w ramach ww. polityki. Niemniej zawodność rynku wskazywana przez koncepcje wywodzące się z ekonomii neoklasycznej, polegająca na występowaniu niewystarczających bodźców do inwestowania w rozwój wiedzy, to zdecydowanie zbyt ogólna przesłanka do podjęcia przez państwo interwencji za pomocą omawianych instrumentów. Ze względu na międzynarodowy charakter działalności wielu przedsiębiorstw, jak i z uwagi na ryzyko prowadzenia przez państwa konkurencji podatkowej w zakresie stosowanych bodźców podatkowych, właściwemu zaprojektowaniu wskazanych instrumentów polityki innowacyjnej sprzyjać będą koncepcje wywodzące się z ekonomii ewolucyjnej (dzięki odwołaniu do wyników osiąganych i narzędzi stosowanych w ramach innych systemów innowacji). 
Bodźce podatkowe wspierające działalność $\mathrm{B}+\mathrm{R}$ należą do grupy najpopularniejszych instrumentów polityki innowacyjnej. Popularność tych instrumentów nie wynika jednak z ich wyjątkowej efektywności - pod tym względem bodźce podatkowe są porównywalne $z$ instrumentami bezpośredniego wsparcia działalności B+R. Choć bilans korzyści i wad stosowania tych instrumentów również nie wydaje się szczególnie atrakcyjny (w porównaniu z instrumentami bezpośrednimi), nie można wykluczyć, że niski koszt administracyjny wykorzystania tych narzędzi będzie w wielu przypadkach istotnym argumentem przemawiającym za ich wyborem. Natomiast jeżeli chodzi o inne czynniki, które przyczyniły się do wzrostu popularności omawianych bodźców podatkowych, znaczącą rolę odegrały w tym zakresie opisane w niniejszym artykule procesy i zmiany zachodzące $\mathrm{w}$ środowisku międzynarodowym. Powyższe procesy i zmiany pozostają także w ścisłym związku z rosnącą hojnością władz państwowych, jeżeli chodzi o wysokość wsparcia przekazywanego przedsiębiorcom na prowadzenie działalności B+R przy wykorzystaniu bodźców podatkowych.

Duża popularność bodźców podatkowych wspierających działalność B+R w Europie (jak i na całym świecie) przez długi czas znajdowała jedynie minimalne odzwierciedlenie, jeżeli chodzi o wykorzystanie ww. instrumentów w Polsce. Sytuacja ta była spowodowana nie tyle brakiem potrzeby interwencji państwa w zakresie wsparcia działalności B+R, co wykorzystywaniem do tego celu instrumentów bezpośrednich. Jak wcześniej wspomniano, istotnym impulsem rozwoju polityki innowacyjnej w Polsce było członkostwo w Unii Europejskiej i związana z nim możliwości sfinansowania wielu interwencji przeprowadzanych w ramach tej polityki ze środków pochodzących z funduszy strukturalnych UE. Programy operacyjne, które zostały utworzone na potrzeby dystrybucji ww. środków unijnych, sprzyjały wspieraniu działalności $\mathrm{B}+\mathrm{R}$ za pomocą instrumentów bezpośrednich. Zmiana $\mathrm{w}$ zakresie prowadzonej polityki, tj. wprowadzona w $2016 \mathrm{r}$. ulga podatkowa na $\mathrm{B}+\mathrm{R}$, to próba stworzenia skutecznego modelu wspierania innowacyjności w Polsce bez ograniczania się do uwarunkowań wykorzystania środków unijnych, które są dostępne w ramach programów operacyjnych. Działanie to jest oczywiście konsekwencją niezadowalających efektów prowadzonej wcześniej polityki. Ocena ww. efektów została przeprowadzona na podstawie porównań międzynarodowych, a interwencja państwa polegająca na wprowadzeniu bodźców podatkowych stymulujących rozwój działalności $\mathrm{B}+\mathrm{R}$ była uzasadniana za pomocą argumentów odwołujących się do teorii systemów innowacji. Wprowadzone w Polsce w 2016 r. ulgi podatkowe stają się z każdym rokiem coraz hojniejsze, co wpisuje się w trend obserwowany (w ujęciu długoterminowym) w skali międzynarodowej. 


\section{Bibliografia}

Bérubé, Ch., Mohnen, P. (2009). Are firms that receive R\&D subsidies more innovative?. Canadian Journal of Economics, $\mathrm{nr}$ 42(1). http://dx.doi.org/10.1111/j.1540-5982.2008.01505.x

Busom, I., Corchuelo, B., Martínez-Ros, E. (2014). Tax incentives... or subsidies for business $\mathrm{R} \& \mathrm{D}$ ?. Small Business Economics, nr 43(3).

Carvalho, A. (2012). Why are Tax Incentives Increasingly Used to Promote Private R\&D?, w: G.T. Papanikos (red.). Economic Essays. Athens: Athens Institute for Education and Research.

Chaminade, C., Edquist, C., Rationales for public policy intervention in the innovation process: A system of innovation approach. http://staff.circle.lu.se/cristina.chaminade/wp-content/ uploads/2015/09/Cham-Edq-Rationales-submitted-dec06-Book-innovation-policy.pdf

Cornell Univeristy, INSEAD i WIPO (2018). Global Innovation Index 2018: Energizing the World with Innovation. Fontainebleau, Ihaca and Geneva 2018.

Edler, J., Cunningham, P., Gök, A., Shapira, P. (2016). Introduction: Making sense of innovation policy, w: J. Edler, P. Cunningham, A. Gök, P. Shapira (red.). Handbook of Innovation Policy Impact. Cheltenham, UK; Northampton, MA, USA: Edward Elgar Publishing.

Edquist, C. (2011). Design of innovation policy through diagnostic analysis: identification of systemic problems (or failures). Industrial and Corporate Change, nr 20(6). https://doi. org/10.1093/icc/dtr060

Edquist, C. (red.). (1997). Systems of Innovation: Technologies, Institutions and Organisations. London: Pinter.

Elschner, C. $i$ in. (2011). What the design of an R\&D tax incentive tells about its effectiveness: a simulation of $\mathrm{R} \& \mathrm{D}$ tax incentives in the European Union. The Journal of Technology Transfer, nr 36(3). http://dx.doi.org/10.1007/s10961-009-9146-y

European Commission (2002). Report on research and development (EPC/ECFIN/01/777-EN Final, January), Brussels.

European Commision (2014). A study on RઐD Tax Incentives: Final Report. http://ec.europa.eu/ taxation_customs/resources/documents/taxation/gen_info/economic_analysis/tax_papers/ taxation_paper_52.pdf

Freeman, C. (1988). The Economics of Industrial Innovation. London: Pinter.

Hall, B., Van Reenen, J. (2000). How effective are fiscal incentives for R\&D? A review of the evidence. Research Policy, nr 29 (4-5). http://dx.doi.org/10.1016/S0048-7333(99) 00085-2

Hämäläinen, T.J. (2003). National Competitiveness and Economic Growth. The Changing Determinants of Economic Performance in the World Economy. Cheltenham, UK; Northampton, MA, USA: Edward Elgar Publishing.

Jasiński, A.H. (2013). Instrumenty polityki innowacyjnej: Czy grają w Polsce?. Zagadnienia Naukoznawstwa, nr 1(195).

Klein Woolthuis, R., Lankhuizen, M., Gilsing, V. (2005). A system failure framework for innovation policy design. Technovation, $\mathrm{nr} 25(6)$. 
Lundvall, B.Å., Borrás, S. (2007). Science, Technology, and Innovation Policy, w: J. Fagerberg, D.C. Mowery, R.R. Nelson (red.). The Oxford Handbook of Innovation. New York: Oxford University Press.

Lundvall, B.Å. (1992). National Systems of Innovation: Towards a Theory of Innovation and Interactive Learning. London: Pinter Publishers.

Mazzucato, M. (2015). Innovation systems: from fixing market failures to creating markets. Revista do Serviço Público, Brasília, nr 66(4).

Mazzucato, M., Penna, C. (2014). Beyond market failures: the market creating and shaping role of state investment banks. Working Paper Series. University of Sussex SPRU.

Nelson, R.R. (1993). National Innovation Systems: A Comparative Study. Oxford: Oxford University Press.

OECD (2014). Tax incentives for R\&D and innovation, w: OECD, Science, Technology and Industry Outlook 2014. Paris: OECD Publishing. http://dx.doi.org/10.1787/sti_outlook-2014-en

OECD (2017). R๘D tax incentives, w: OECD Science, Technology and Industry Scoreboard 2017: The digital transformation. Paris: OECD Publishing. http://dx.doi.org/10.1787/ sti_scoreboard-2017-26-en

Rosenberg, N. (1982). Inside the Black Box, Cambridge: Cambridge University Press.

Rosenberg, N. (1994). Exploring the Black Box: Technology, Economics and History. Cambridge: Cambridge University Press.

Starczewska-Krzysztoszek, M. (2007). Konkurencyjność sektora MSP w 2007 r. (raport z badań „Monitoring kondycji sektora MSP 2007”). Warszawa: Polska Konfederacja Pracodawców Prywatnych Lewiatan.

Stryjek, J. (2015). Polityka innowacyjna i narodowy system innowacji w Polsce. Kwartalnik Kolegium Ekonomiczno-Społecznego Studia i Prace, nr 1.

Ustawa z dnia 29 lipca 2005 r. o niektórych formach wspierania działalności innowacyjnej, Dz. U. 2005, nr 179, poz. 1484.

Ustawa z dnia 25 września 2015 r. o zmianie niektórych ustaw w związku ze wspieraniem innowacyjności, Dz. U. 2015, poz. 1767.

Ustawa z dnia 4 listopada 2016 r. o zmianie niektórych ustaw określających warunki prowadzenia działalności innowacyjnej, Dz. U. 2016, poz. 1933.

Ustawa z dnia 9 listopada 2017 r. o zmianie niektórych ustaw w celu poprawy otoczenia prawnego działalności innowacyjnej, Dz. U. 2017, poz. 2201.

Uzasadnienie do projektu Ustawy o zmianie niektórych ustaw w związku ze wspieraniem innowacyjności. Druk Sejmowy nr 3286. Warszawa, 13 marca 2015.

Weresa, M.A. (2012). Systemy innowacyjne we wspótczesnej gospodarce światowej. Warszawa: Wydawnictwo Naukowe PWN.

Yang, C.-H. et al. (2012). Tax incentives and R\&D activity: Firm-level evidence from Taiwan. Research Policy, nr 41(9). 